UDC 613.2

DOI: $10.21668 /$ health.risk/2018.4.02.eng

\title{
ANALYSIS OF POPULATION HEALTH RISKS IN THE RUSSIAN FEDERATION CAUSED BY FOOD PRODUCTS CONTAMINATION
}

\author{
N.V. Zaitseva \\ Federal Scientific Center for Medical and Preventive Health Risk Management Technologies, 82 Monastyrskaya \\ Str., Perm, 614045, Russian Federation
}

\begin{abstract}
Analysis of population health risks related to food products is a most promising sphere for international cooperation between the Eurasian Economic Union (EAEU) member states and economically developed countries. And it is truly vital to harmonize key aspects of the process. Methodology of population health risk analysis is considered to be a basic tool for providing food products safety in the Russian Federation.

Harmonization takes place simultaneously with creation, development, and implementation of all the instruments related to risk analysis components in the Russian Federation: risk assessment, risk management, and informing about risks. In the EAEU countries and in the RF, experts apply evolution mathematical modeling to describe impacts exerted by dangerous chemicals and biological agents on functions of body organs and systems when they assess risks related to food products. Markers of exposure and effect together with epidemiologic models give information grounds for establishing regularities in relationships and calculation of parameters for consequent health risk assessment. Established regularities together with experience that was accumulated due to physiological processes modeling gave grounds for multi-level modeling of health risk evolution. Such models allow to predict negative effects both for critical organs and systems and a body as a whole.

Approaches have been tested when substantiating hygienic safety criteria for some food contaminants. New tasks are set; it is necessary to develop a regulatory basis for assessing health risks related to food contamination and property losses borne by a consumer due to such risks; to speed up development and implementation of harmonized risk-based quality standards as criteria of food safety for health and their application in control and surveillance activities; to improve information basis for health risk assessment and development of international cooperation on issues related to analyzing health risks caused by food products contamination.
\end{abstract}

Key words: risk assessment, risk management, mathematical modeling, food products, safety, cooperation.

Food safety in the Russian Federation is considered to be one of the basic factors that help to preserve its national sovereignty. It is also a most essential part of the demographic policy and a necessary condition for improving life quality of Russian citizens. The latter is a top strategic national priority and it can be achieved via guaranteeing high living standards. Procedures for population health risks analysis are considered in the RF to be a basic instrument for providing food products safety [1-5].

There is a multi-level system of legal regulations developed in the RF and the EAEU countries. It regulates health risks analysis including risks caused by food products contamination [6]. This system consists of such legal documents as the Customs Union Technical
Regulations and the RF Federal Laws. The RF Federal Law "On Technical Regulation"1 states that products safety, including food products, means absence of any intolerable risk for people's life and health. Requirements to products which include absence of intolerable risk are fixed in technical regulations.

Analysis of health risks for the RF population which are caused by food products contamination is performed within a legal framework existing in the RF and EAEU. This framework includes both legal and subordinate acts as well as regulatory and methodical documents. Legal documents are the Customs Union Technical Regulations (CU TR), such as, for example, "On food products safety", "TR for juice products made of fruit and vege-

(C) Zaitseva N.V., 2018

Nina V. Zaitseva - Academician of the Russian Academy of Sciences, Doctor of Medical Sciences, Professor, Scientific Director (e-mail: znv@fcrisk.ru; tel.: +7 (342) 237-25-34; ORCID: https://orcid.org/0000-0003-2356-1145).

${ }^{1}$ On technical regulation: The Federal Law No. 184-FL issued on December 27, 2002 [web-source] // KonsultantPlus. URL: http://www.consultant.ru/document/cons_doc_LAW_40241/ (date of visit September 16, 2018). 
tables", "On grain safety", "TR for fat and oil products" ${ }^{2}$ etc. The RF Government Regulation "On application of risk-oriented approach when organizing specific types of the state control (surveillance) activities and making alterations into some RF Government Regulations" ${ }^{3}$ issued on August 17, 2016 No. 806 (edited on March 30, 2017) is one of the most important subordinate acts in the sphere.

Analysis of health risks caused by food products is one of the most promising spheres for international cooperation between the Eurasian Economic Union (EAEU) member states and economically developed countries. And it is most essential to harmonize its key aspects $[7,8]$.

Health risk analysis is a process which consists of three components: risk assessment, risk management, and risk communications; therefore, all three components need to be harmonized but with allowance for peculiarities they all have. It is advisable to get better insight into harmonization of risk analysis systems, first of all, their legal aspects and key principles.

We analyzed experience in harmonizing risk assessment procedures accumulated in the European Union, and it allowed us to identify other critical components in the process: harmonization of health risk assessment techniques and criteria [9-11].

A key aspect here is harmonization of legislation in the risk analysis sphere. Such harmonization of legal grounds for analyzing risks of food products contamination should be based on convergence between legal regulation existing in the EAEU and the RF and standards fixed by the WTO and Codex Alimentarius Commission. There are a lot of positive examples in the field. Basic regulations fixed in laws "On Technical Regulation" which are adopted in the EAEU member states are almost completely harmonized with similar legal documents existing in the developed countries. Thus, in order to harmonize legal grounds existing in the EAEU countries with the WTO standards on sanitary and phytosanitary measures, basic principles and rules for sanitary and phytosanitary measures application were included into the Treaty on the EAEU dated May 29, 2014. However, a lot is left to be implemented. For example, to develop the Russian Federation legislation further, we need to introduce new legal regulations on risk analysis into the Law "On sanitary-epidemiologic welfare of the population" ${ }^{4}$; these new regulations are to be harmonized with the legislative practices existing in Europe.

Regulations on risk assessment fixed in the "Declaration on Working Principles for Risk Analysis for Food Safety" issued by the Codex Alimentarius Commission gave grounds for convergence between risk assessment principles adopted in the RF and world practices in the field. These regulations are now fixed in some regulatory and methodical documents both adopted and being now considered ${ }^{5}$ etc.

${ }^{2}$ CU TR 021/2011. On food products safety: The Customs Union Technical Regulations [web-source] // KODEKS: an electronic fund of legal and reference documentation. - URL: http://docs.cntd.ru/document/902320560 (date of visit September 16, 2018). CU TR 023/2011. TR for juice products made of fruits and vegetables: The Customs Union Technical Regulations [websource] // KODEKS: an electronic fund of legal and reference documentation. - URL: http://docs.cntd.ru/document/902320562 (date of visit September 20,2018). TR 201_/00_/ CU. On grain safety. The Customs Union Technical Regulations [web-source] // KODEKS: an electronic fund of legal and reference documentation. - URL: http://docs.cntd.ru/document/1200083846 (date of visit September 20, 2018). CU TR 024/2011. Technical Regulations for fat and oil products (last edited on April 23, 2015) [web-source] // KODEKS: an electronic fund of legal and reference documentation. - URL: http://docs.cntd.ru/document/902320571 (date of visit September 20, 2018).

${ }^{3}$ On application of risk-oriented approach when organizing specific types of the state control (surveillance) activities and making alterations into some RF Governmental Regulations: The RF Governmental Order Issued on August 17, 2016 N 806 [websource] // KonsultantPlus. - URL: http://www.consultant.ru/document/cons_doc_LAW_203819/(date of visit September 20, 2018).

${ }^{4}$ On sanitary-epidemiologic welfare of the population: The RF Federal law No. 52-FL issued on March 30, $1999 \mathrm{~N}$ [websource] // KonsultantPlus. - URL: http://www.consultant.ru/document/cons_doc_LAW_22481 (date of visit September 20, 2018).

${ }^{5}$ MG 2.1.10.0067-12. Population health risk assessment under exposure to microbe factors contained in food products. Methodical grounds, principles and assessment criteria: Methodical Guidelines [web-source] // KODEKS: an electronic fund of legal and reference documentation. - URL: http://docs.cntd.ru/document/1200095230 (date of visit September 16, 2018). SER "Sanitary requirements to providing safety of the environment and products for population health" (a draft). 
According to Working Principles for Risk Analysis for Food Safety issued by the Codex Alimentarius Commission, risk analysis should:

- be systemic and consistent;

- be open and transparent;

- envisage some functional distinction between risk assessment and measures aimed at its prevention and minimization;

- include assessment and revision of the results when fresh scientific data are obtained.

Implementation of basic principles for risk analysis, for example, its systemacy and consistence, is fixed in regulatory documents which set forth Rospotrebnadzor functions and authority. According to the Provisions for the Federal Service, it has the following authority:

- as regards risk assessment: to organize and conduct necessary inspections and assessment, including those related to surveillance in the food products safety sphere;

- as regards risk management: to perform surveillance and control over conformity with the obligatory legislative requirements to food products;

- as regards risk communication: to inform state authorities and the population about all the measures taken to provide sanitaryepidemiologic welfare of the population including managing health risks caused by food products. Structural approach to risk analysis is implemented in full conformity with "The Provisions for the Federal Service for Surveillance over Consumer Rights protection and Human Well-being"6.

Functional distinction between risk assessment performed by expert organizations and implementation of measures aimed at risk prevention and minimization conducted by surveillance authorities also fully corresponds to risk analysis principles. Risk assessment is to be performed by 85 centers for hygiene and epidemiology and 29 scientific-research or- ganizations; risk management and risk communications are to be accomplished by 84 Rospotrebnadzor regional offices. Rospotrebnadzor scientific-research institutions are responsible for working out methodical and regulatory grounds for health risk assessment and management. These institutions develop up-to-date models and criteria for health risk assessment and classification, including risks related to food products.

Common concepts on permissible health risks levels are one of the most vital issues related to harmonization of assessment criteria for risks caused by consumer products; it is especially true for food products. Internationally accepted risks levels classification, from De Manifestis to De Minimus (Table 1) is applied in health risk assessment practices in Russia. Risk value equal to $1 \cdot 10^{-4}$ is considered to be a permissible risk level for consumers and the population in general.

Harmonization is taking place simultaneously with creation, development and implementation of tools for all the risk analysis components in the RF: risk assessment, risk management, and risk communications.

We can spot out development of theoretical grounds for analysis of health risks caused by food products as one of the basic aspects in the process [12]. The Russian Academy of Sciences and Rospotrebnadzor have accumulated certain experience related to development of fundamental grounds for assessing health risks caused by food products contamination [13-15].

The most interesting findings related to assessing health risks caused by food products contamination are:

- mathematical modeling of body functions;

- analysis of interpolation of impacts exerted by chemical and biological factors; markers.

- substantiation for a set of biological

${ }^{6}$ On Approval of Provisions about the Federal Service for Surveillance over Consumer Rights Protection and Human Wellbeing: The RF Governmental Order issued on June 30, 2004 No. 322 [web-source] // Garant. - URL: http://base.garant.ru/12136005/ (date of visit September 18, 2018). 
Risk levels classification ${ }^{7}$

\begin{tabular}{|l|c|}
\hline \multicolumn{1}{|c|}{ Risk level } & $\begin{array}{c}\text { Individual lifelong risk } \\
\text { of a grave disease or death }\end{array}$ \\
\hline $\begin{array}{l}\text { High (De Manifestis) risk; is not acceptable; it is necessary to imple- } \\
\text { ment activities aimed at its elimination or reduction }\end{array}$ & $>10^{-3}$ \\
\hline $\begin{array}{l}\text { Average risk; when population is exposed to it, it is necessary to per- } \\
\text { form dynamic control and profound examination of risk sources and } \\
\text { possible consequences of adverse impacts in order to make a decision } \\
\text { on risk management measures }\end{array}$ & $10^{-3}-10^{-4}$ \\
\hline $\begin{array}{l}\text { Low risk; is acceptable (this is generally a level hygienic standards } \\
\text { are set at) }\end{array}$ & $10^{-4}-10^{-6}$ \\
\hline $\begin{array}{l}\text { Minimal (De Minimus) risk; this is a desirable (target) risk level which } \\
\text { can be detected during prevention activities }\end{array}$ & $<10^{-6}$ \\
\hline
\end{tabular}

Health risk assessment is a hygienic and biologically oriented examination. Results of research on regularities in a pathological process and its modification under exposure to risk factors are a fundamental basis for it. Biokinetic modeling of body organs and systems is essential for health risk assessment. Creation of mathematical models for specific systems, and in future for the whole human body, can give grounds for simulation prediction of its responses to impacts exerted by risk factors related to food products. We can consider the following examples: simulation prediction of negative consequences for functional state of some gastrointestinal tract sections which can be caused by certain food products consumption $[16,17]$, as well as impacts exerted by chemical risk factors on the immune and neuroendocrine systems [18].

Probabilistic and deterministic modeling techniques are applied in world practice. In spite of being very promising, probabilistic models are quite rare these days. "Methodology for health risk assessment..." [19] recommended by the EAEU proposes to apply improved deterministic risk evolution models for risk assessment.

When we consider various aspects of mathematic modeling, we should pay closer attention to an issue related to interpolation of impacts exerted by chemical and biological factors of food products. For example, residual quantities of chemical anti-microbe prepa- rations can result both in creation of microflora which is resistant to them and in gut organisms imbalance [20-22]. Mathematical modeling of relationship between a relative gut organisms number and tetracycline concentration reveals prevailing inhibition of obligate microorganisms.

A principle regularity in replacement of obligate gut microorganisms with facultative ones is shown in Figures 1 and 2.

The process results in $4 \%$ higher risks of the digestive system diseases (the gastrointestinal tract diseases and food allergy) and 8\% higher risk of immune-dependent health disorders (blood diseases and immune disorders).

Elements included into the technique are being improved at each stage in risk assessment. Thus, at risk identification stage, in order to select most susceptible population groups, it is advisable to apply biological parameters which allow for individual peculiarities of a body. Candidate genes polymorphisms can be used as indicators of individual sensitivity to impacts exerted by adverse chemicals in food products (Figure 3). These indicators are quite specific in terms of a probable negative effect exerted by a specific contaminant.

A key task at risk identification stage, the first one in risk assessment, is a preliminary aggregation of all the available data on a sphere where a risk is detected, its indicators, and basic elements of a security system.

${ }^{7} \mathrm{G}$ 2.1.10.1920-04. Guidelines on assessment of population health risk under exposure to chemicals which pollute environment. - M.: Federal Center of State Sanitary and Epidemic Surveillance, RF Public Health Ministry, 2004. - 143 p. 


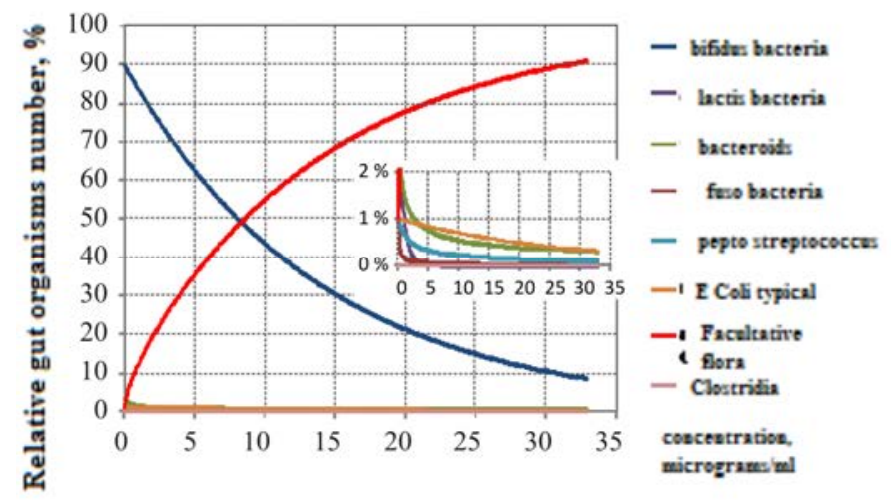

Figure 1. A relationship between relative gut organisms number (\%) and tetracycline concentration

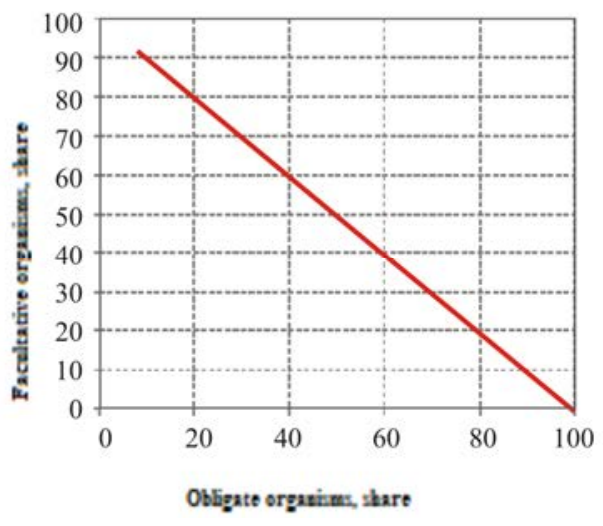

Figure 2. A ratio of obligate and facultative gut organisms

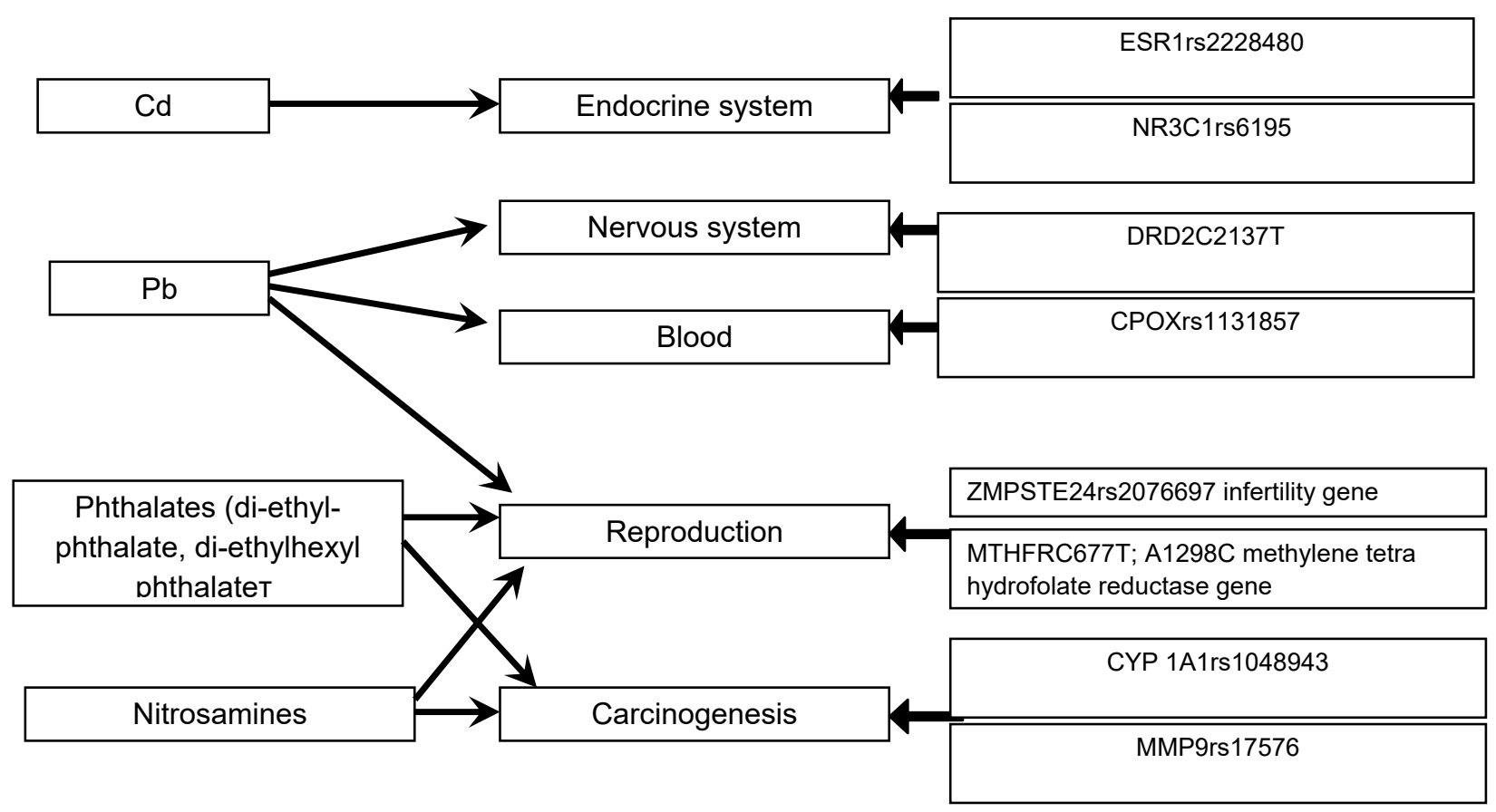

Figure 3. Indicators of individual sensitivity to impacts exerted by adverse chemicals in food products: candidate genes polymorphisms

Contemporary threats, for example, microorganisms being resistant to anti-microbe preparations, require development of corresponding forms for submission of necessary data (risk profiles). Thus, when we develop a risk profile for salmonellas which are resistant to anti-microbe preparations (AMP), we highlight such priority products and manufacturing processes in risk sphere description which can be dangerous as per a criterion of being contaminated with AMP-resistant salmonellas (eggs and poultry, poultry farming); we spot out possible ways of AMP occurrence (appli- cation of fluoroquinolones in feed and in birds treatment); we describe potential health risks for consumers (greater number of salmonellosis with average and/or severe gravity); we enlist possible activities aimed at reduction in resistant microorganisms number (control over application of fluoroquinolones in poultry production). We also propose risk indicators, the basic ones being a share of resistant microorganisms in food products (up to $60 \%$ of salmonellas detected in poultry meat are resistant to fluoroquinolones), a share of food products contaminated with resistant microorganisms 
(up to $22 \%$ of poultry meat is contaminated with resistant salmonellas). We identified the following basic elements in the security system: HACCP system and monitoring over microbe contamination and residual AMP quantities (control over disinfection of equipment at poultry farms and factories, monitoring over fluoroquinolones application in manufacturing processes) and measures aimed at reduction of food contamination with AMP-resistant microorganisms.

Exposure assessment stage requires chemical and analytical support. Apart from quite developed techniques for identification of hazardous factors in food products, exposure markers determination is also essential for health risk assessment validity. Exposure markers are concentrations of either contaminants themselves or their metabolites in biological media; here we can apply, for example, mass-spectrometry with inductively coupled plasma to detect metals, or high performance liquid chromatography to detect phthalates and di-methyl ether of terephthalic acid in blood or urine; capillary gas chromatography is applied to detect nitrosamines in blood, etc.

Together with exposure markers, a set of immunologic, biochemical, genetic and other markers of an effect is applied at the stage when "exposure - effect (response)" relationship is assessed. Thus, for example, parameters characterizing disorders in processes regulation associated with metabolites, proteome, immune and genetic state of a body, are applied as markers of an effect caused by some food contaminants (Table 2).

Markers of exposure and effect together with epidemiologic models create informational background for detecting regularities and calculating parameters for further health risk assessment. Detected regularities along with experience accumulated in simulation modeling of physiological processes gave grounds for multi-level modeling of health risk evolution. Such models allow to predict negative effects both for critical systems and organs and for a body as a whole.

Risk evolution model which describes disorders in human body functions has a number of advantages. They are a possibility to simulate risk accumulation; risk assessment for preset exposure scenarios; calculation of reduction in expected life span; classification of risk levels with risk acceptability assessment.

Table 2

Markers of effects produced by some food contaminants

\begin{tabular}{|l|l|l|}
\hline $\begin{array}{c}\text { Food } \\
\text { contaminant }\end{array}$ & \multicolumn{1}{|c|}{ Effect } & \multicolumn{1}{|c|}{$\begin{array}{c}\text { Markers } \\
\text { of effect }\end{array}$} \\
\hline Phthalates & $\begin{array}{l}\text { Endocrine and } \\
\text { reproductive } \\
\text { state disorders }\end{array}$ & $\begin{array}{l}\text { Increase in LDLP, } \\
\text { sex hormones im- } \\
\text { balance, leptin } \\
\text { deficiency }\end{array}$ \\
\hline $\mathrm{Cd}$ & $\begin{array}{l}\text { Endocrine } \\
\text { state disorders }\end{array}$ & $\begin{array}{l}\text { Testosterone con- } \\
\text { tents imbalance, } \\
\text { a/spermic antibod- } \\
\text { ies }\end{array}$ \\
\hline $\mathrm{Pb}$ & $\begin{array}{l}\text { Nervous state } \\
\text { disorders }\end{array}$ & $\begin{array}{l}\text { Decrease in sero- } \\
\text { tonin content }\end{array}$ \\
\cline { 2 - 3 } & $\begin{array}{l}\text { Hemopoiesis } \\
\text { disorders }\end{array}$ & $\begin{array}{l}\text { Increase in DALA } \\
\text { content in urine, } \\
\text { anemia }\end{array}$ \\
\cline { 2 - 3 } & $\begin{array}{l}\text { Reproductive } \\
\text { state disorders }\end{array}$ & $\begin{array}{l}\text { Sex hormones im- } \\
\text { balance, hyperpro- } \\
\text { duction of HAFP, } \\
\text { HHGT }\end{array}$ \\
\hline Nitrosamines & Carcinogenesis & $\begin{array}{l}\text { Hyperproduction } \\
\text { of oncomarkers } \\
\text { (HAFP, CA199, } \\
\text { CA724, CA242) }\end{array}$ \\
\hline
\end{tabular}

These possibilities were applied on the basis of harmonized procedures when experts (including the author of this paper) assessed health risk caused by ractopamine entering a body under various conditions and validated that its content in meat products was not acceptable. It was shown that, given an average level of animal products consumption by the RF population, permissible residual content of ractopamine recommended by Codex Alimentarius Commission is (scenario 1) substantially higher than in the case when ractopamine is introduced in quantities equal to the lower limit of its quantitative determination in tissues (3-5 $\mu \mathrm{g} / \mathrm{kg}$ ) (scenario 2). Figures 4 and 5 show the results of health risk evolution modeling under exposure to ractopamine. 
The suggested methodical approaches to risk evolution modeling taking into account experience of their application gave grounds for health risk assessment methodology. It is usually applied to assess risks caused by exposure to chemical, physical, and biological factors and to determine safety of products (goods) according to parameters recommended by the Eurasian Economic Commission. These methodical approaches allow not only to assess and classify multi-factor lifelong risks, but also to determine their structure as per factors and responses.

Risk characteristics with estimated index calculation underlie differentiation of risk management measures which can be as tough as total withdrawal of food products from markets provided that risk level is very high (Table 3).

Risk management related to risks caused by food products include such priority spheres as management procedures development (risky supplies, HACCP); optimization of surveillance and control activities; validation of hygienic requirements and standards as per acceptable risk criteria.

Regulatory documents that determine the system of managing health risks related to food products in the Russian Federation are for the most part harmonized with world practices, first of all, with European standards. HACCP basic principles and the necessity of their implementation are fixed in the EAEU legislation on technical regulation.

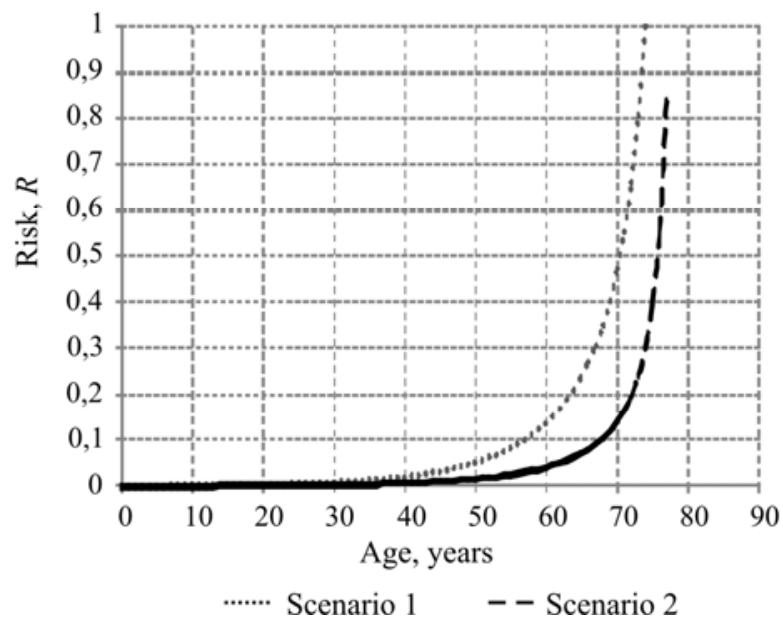

Figure 5. Reduced risk of functional disorders in the cardiovascular system

Figure 4. Additional risk of functional disorders in the cardiovascular system

Risk management measures chosen as per results of risk evolution assessment

\begin{tabular}{|c|c|l|}
\hline $\begin{array}{c}\text { Estimated } \\
\text { index of risk }\end{array}$ & $\begin{array}{c}\text { Products risks } \\
\text { characteristics }\end{array}$ & \multicolumn{1}{c|}{ Risk management measures } \\
\hline Lower than 0.05 & Negligible risk & $\begin{array}{l}\text { Any measures are applied only if there are complaints or recla- } \\
\text { mations }\end{array}$ \\
\hline $0.05-0.35$ & Moderate risk & $\begin{array}{l}\text { Risk communication (labeling) } \\
\text { Risk minimization at stages when a product is designed or } \\
\text { manufactured }\end{array}$ \\
\hline $0.35-0.6$ & High risk & $\begin{array}{l}\text { A product is included into risky supplied category } \\
\text { Risk communication } \\
\text { Limitations imposed on product output and application }\end{array}$ \\
\hline Higher than 0.6 & Vey high risk & $\begin{array}{l}\text { A product is included into risky supplied category } \\
\text { Urgent risk communication } \\
\text { A product is withdrawn from the market }\end{array}$ \\
\hline
\end{tabular}


Table 4

Estimation matrix for health risk level applied to assign a product into risky supplies

\begin{tabular}{|l|c|c|c|c|}
\hline \multicolumn{2}{|c|}{$\begin{array}{c}\text { Probability of } \\
\text { health disorders } \\
\text { caused by product } \\
\text { application }\end{array}$} & \multicolumn{3}{|c|}{ Health disorder gravity } \\
\cline { 3 - 5 } & Grave & Average & Mild \\
\hline $\begin{array}{l}\text { Very } \\
\text { high }\end{array}$ & $1 / 10$ & $\begin{array}{c}\text { Very } \\
\text { high }\end{array}$ & $\begin{array}{c}\text { Very } \\
\text { high }\end{array}$ & High \\
\hline High & $1 / 100$ & $\begin{array}{c}\text { Very } \\
\text { high }\end{array}$ & High & Moderate \\
\hline Average & $1 / 1000$ & High & Moderate & Low \\
\hline Low & $1 / 10000$ & Moderate & Low & Low \\
\hline
\end{tabular}

Risky supplied identification is one of tools for managing consumer health risks caused by food products. Experts in the Russian Federation worked out a procedure for assigning food products into intolerable risk group in accordance with the estimation matrix (Table 4).

Low quality products which can cause serious health risk (risk levels are "very high" and "high") should be assigned into risky supplies category. As per assessment results risky products can be registered in the Eurasian Economic Union Information system for technical regulation, sanitary and phytosanitary measures; it can also be registered in the Customs Union integrated information system for external and mutual trade (an information source for "supplies of products which cause intolerable risks").

In 2015 a risk-oriented model for surveillance and control activities performed by Rospotrebnadzor was fixed in the RF legislation on the basis of legislative documents and initiatives [10]. The model called for a new classification, both for food products and objects under surveillance which produced and distributed them. The classification was based on parameters of population risk occurring when fixed requirements were violated $\left(R^{\mathrm{I}}\right)$. Methodical approaches to assessment of these parameters allow not only for probable violations of obligatory requirements to food products and potential health risk but also for regional peculiarities of food products consumption.

$$
R^{I}=\sum_{i}\left(p_{i} \cdot u_{i}\right) \cdot W
$$

where:

$p_{i}$ is probability of obligatory requirements to food products safety being violated; requirements are taken as per $i$-th criterion (factor) during a single inspection. Chemicals, microbiological and parasitic agents, radiological parameters, and genetically modified organisms can be considered hazardous factors, and their contents in products are usually inspected during surveillance and control activities;

$u_{i}$ is relative health risk caused by violation of safety requirements to $i$-th factor in $j$-th product;

$W$ is a coefficient which characterizes regional peculiarities of food products consumption.

When population consume food products which don't correspond to safety requirements, it can cause health risks; basing on a level of such risks, food products can be assigned into one of six basic risk categories, from low to extremely high (Table 5).

Table 5

Estimation matrix for health risk level applied to assign products into risky supply categories

\begin{tabular}{|l|c|}
\hline \multicolumn{1}{|c|}{$\begin{array}{c}\text { Risky supplies } \\
\text { category }\end{array}$} & $\begin{array}{c}\text { Range of potential } \\
\text { health risk values }\left(R^{\mathrm{I}}\right)\end{array}$ \\
\hline Extremely high & $>1^{*} 10-1$ \\
\hline High & $10-2<R \leq 1^{*} 10-1$ \\
\hline Considerable & $10-3<R \leq 1^{*} 10-2$ \\
\hline Average & $10-4<R \leq 1^{*} 10-3$ \\
\hline Moderate & $10-6<R \leq 1^{*} 10-4$ \\
\hline Low & $<10-6$ \\
\hline
\end{tabular}

This classification was tested and it allowed to define that there are no food products in the RF which can be considered as causing extremely high risks. The most significant risks (which are high) are caused by bakery products and confectionary (this group comprises all the types of confectionary, including cream ones), watermelons, fish and fish products. Canned food, milk and dairy products, poultry, soft beverages, etc. are assigned into the considerable risk category. 
The risk-oriented model for surveillance over food products is aimed at protecting consumer rights; to fulfill this function, the suggested classification allows for such a component in any risk as property losses borne by a consumer in situations when legislation requirements were violated. When such type of risk is detected, experts take into account not only a probability of a consumer buying unsafe food products, but also his or her potential property losses caused by impossibility to consume them $\left(R^{\mathrm{II}}\right)$

$$
R^{I I}=p^{I I} \cdot u^{I I} \cdot V
$$

where:

$p^{\text {II }}$ is a probability that a consumer buys unsafe food products; it is estimated as per a share of products which were withdrawn due to control and surveillance activities;

$u^{\text {II }}$ shows potential property losses caused by impossibility to consume a single food product (ruble/kg, ruble/1, ruble/unit etc.);

$V$ is an annual volume of a food product consumption by one person $(\mathrm{kg} /$ year, $1 /$ year, units/year etc.).

A value equal to $70 \%$ of population earnings is considered to be a critical level of property losses risk because a share of population living wage in them amounts to about $30 \%$ in the RF.

A risk category a food product is assigned into determines scope of control required during scheduled inspections. Thus, if a product is considered to cause high or considerable risk, it is a subject to a full scope of laboratory and documentary control. Products from extremely risky category are subject to control as per maximum full list of factors.

Requirements to food products safety are to a significant extent violated due to sanitary legislation being breached at objects where food products are manufactured. Therefore, experts single out six categories of such objects as per potential health risk criteria. Methodical approaches to classification of objects which manufacture food products take into account health risks related to violation of sanitary legislation and borne by workers, population, and consumers. This classification underlies control and surveillance activities planning, first of all, inspections frequency. Thus, for example, it is advisable to hold annually inspections at objects which cause extremely high risk; objects which cause low risks can be released from any scheduled inspections.

The methodical approaches were tested and the tests revealed that potential health risks caused by even a single violation of sanitary legislation can vary significantly depending on a type of an economic entity which manufactures and distributes food products. Thus, for example, it was detected that when sanitary legislation was violated in orphanages where practically all the consumed food products were manufactured in-house, it could do much greater damage than the same situation occurring at industrial enterprises.

Scientific organizations of the Russian Academy of Science, Public Healthcare Ministry, and Rospotrebnadzor have accumulated certain experience in assessing chemical and microbiological risk factors related to food products. This experience was applied in development of hygienic standards as per risk criteria as a part of sanitary legislation. A number of such standards are already developed (maximum permissible levels of ractopamine and tetracycline-type antibiotics in meat products, nitrates in vegetables, and L. Monocytogenes in meat, fish and dairy products).

Risk communications are an essential part of risk analysis; they are exchange of information related to risk factors and levels between food products manufactures and consumers, state and local authorities, experts and civil society institutions.

Traditionally, risk communications in Russia are wrongly replaced with their simplified model, namely, informing about risks. Food products consumers are only passive objects in such a model, and they don't take any active part in discussing risk acceptability and measures taken to manage it. However, today it is advisable to develop a two-sided risk communications model which can provide involvement of all the interested parties into risk management decision-making. Development of a dialogue risk-communications model in 
the food products safety sphere is possible only after certain tasks are solved. They are:

- first of all, low information activity of consumers. Thus, according to data obtained by Russian organizations involved in public opinion studies, more than one third of consumers in Russia practically never pay any attention to labels on food products; as for male consumers, the figure is almost a half;

- secondly, Russians usually don't have any persistent positive attitudes towards savepreserving behavior. As questionnaires results reveal, Russians are well aware of risks related to fast food consumption, but more than one third of respondents buy such food on a regular basis;

- thirdly, it is necessary to improve the overall state system of risk communications, namely, to change information distribution channels and start to use those which are popular among target audiences;

- fourthly, experts are not involved into a substantive dialogue about risks to the extent they should be. Unfortunately, nowadays information on risk provided by experts as per risk assessment results is not adapted either for population or decision makers.

Overall, in spite of wide implementation of risk analysis methodology for assessing risks caused by food products, there are certain tasks which are to be solved in the Russian Federation in the nearest future. They are:

- more substantial inclusion of health risk assessment methodology into the RF sanitary legislation and creation of legislative base for assessment of health risks caused by food products contamination and property losses related to such risks and borne by consumers;

- more prompt development and implementation of harmonized risk-based quality standards as criteria of food products safety for health and their application in control and surveillance activities;

- development of information base for health risk assessment and estimation of property losses borne by consumers including activities performed within monitoring programs;

- wider international cooperation on issues related to analyzing risks of food products contamination including activities organized and held by international organizations.

Funding. The research was not granted any sponsor support.

Conflict of interests. The authors state there is no any conflict of interests.

\section{References}

1. Gordeev A.V., Maslennikova O.A., Vermel'D.F., Altukhov A.I., Bespakhotnyi G.V., Borisenko E.N., Daurskii A.N., Dolgushkin N.K., Zaverukha A.Kh., Nazarenko V.I., Runov B.A., Ul'yanov E.V., Ushachev I.G., Cheshinskii L.S., Dragaitsev V.I., Prokop'ev G.S., Sandu I.S., Silaeva L.P., Starostina I.L., Suglobov A.E. [et al.]. Bezopasnost' Rossii. Pravovye, sotsial'no-ekonomicheskie i nauchno-tekhnicheskie aspekty. Prodovol'stvennaya bezopasnost' [Safety of Russia. Legal, socioeconomic and scientific-technical aspects. Food safety]. Moscow, 2000, vol. 1, pert 1, 537 p. (in Russian).

2. Tutel'yan V.A., Nikityuk D.B., Khotimchenko S.A. Normative base for food quality and safety assessment. Russian Journal of Rehabilitation Medicine, 2017, no. 2, pp. 74-120 (in Russian).

3. Edelev D.A., Kantere V.M., Matison V.A. An estimation of risks - the major element of a risk management of food production. Pishchevaya promyshlennost', 2011, no. 9, pp. 14-16 (in Russian).

4. Matison V.A., Arutyunova N.I. The Risk - Based Approach to Ensure the Safety and Quality of Food. Pishchevaya promyshlennost', 2016, no. 5, pp. 16-20 (in Russian).

5. Altukhov A.I., Afanas'ev V.A., Baturin A.K., Butkovskii V.A., Glushchenko V.D., Zlochevskii A.L., Izmailov V.A., Il'ina O.A., Iunikhina V.S., Kislov S.V., Kraus S.V., Kustov V.N., Kovalev Yu.I., Mamikonyan M.L., Moshkovich V.N., Nechaev A.P., Nosenko S.M., Ovechkin A.B., Ponomarev A.N., Tutel'yan V.A. [et al.]. [Food independence of Russia in 2 volumes]. Moscow, Tekhnologiya TsT Publ., 2016, vol. 1, 560 p. (in Russian).

6. Nurgalieva M.T., Smagulov A.K., Iskakova Zh.A. the issues of quality and safety control of food products in the framework of EU and EEU. Nauka i Mir, 2016, vol. 1, no. 3 (31), pp. 86-91 (in Russian).

7. The Future of Risk Assessment in the European Union: The Second report on the Harmonisation of Risk Assessment Procedures / Scientific Steering Committee, EU. Brussels, 2003, 112 p. 
8. Nikitin S. About Russia's accession to the Agreement on the Application of Sanitary and Phytosanitary measures of the WTO. Mezhdunarodnyi sel'skokhozyaistvennyi zhurnal, 2009, no. 4, pp. 3-6 (in Russain).

9. Matison V.A., Yasinov O.Yu. Food Safety: Research and Training. Pishchevaya promyshlennost', 2017, no. 4, pp. 21-24 (in Russian).

10. Berketova L.V., Kryukova E.V. Analiz riskov pri obespechenii bezopasnosti produktov pitaniya [Risk analysis in providing food products safety]. Voprosy pitaniya, 2014, vol. 83, no. S3, pp. 153 (in Russian).

11. Makarov D.A., Komarov A.A., Selimov R.N. Obespechenie khimicheskoi bezopasnosti pishchevoi produktsii v Rossiiskoi Federatsii [Providing chemical safety of food products in the Russian Federation]. Kontrol' kachestva produktsii, 2017, no. 5, pp. 21-26 (in Russian).

12. Zaitseva N.V., Popova A.Yu., May I.V., Shur P.Z. Methods and technologies of health risk analysis in the system of state management under assurance of the sanitation and epidemiological welfare of population. Gigiena i sanitariya, 2015, vol. 94, no. 2, pp. 93-98 (in Russian).

13. Zaitseva N.V., Shur P.Z., May I.V., Kir'yanov D.A. Approaches to the assessment of integrated health risk population based on evolution of mathematical models. Zdorov'e naseleniya i sreda obitaniya, 2011, vol. 223, no. 10, pp. 6-9 (in Russian).

14. Zaitseva N.V., May I.V., Kir'yanov D.A., Sboev A.S., Andreeva E.E. Conceptual and methodological aspects of improving the effectiveness of control and supervisory activities based on hazard and risk assessment and estimation of harm to health of the population. Zdorov'e naseleniya $i$ sreda obitaniya, 2014, vol. 261, no. 12, pp. 4-7 (in Russian).

15. First report on the harmonisation of risk assessment procedures. Part 1: The Report of the Scientific Steering Committee's Working Group on Harmonisation of Risk Assessment Procedures in the Scientific Committees advising the European Commission in the area of human and environmental health 26-27 October 2000 (published on the internet 20.12.2000). Available at: https://mobil.bfr.bund.de/cm/343/first_report_on_the_harmonisation_of_risk_assessment_procedures.pdf (16.09.2018).

16. Trusov P.V., Zaitseva N.V., Kamaltdinov M.R. A multiphase flow in the antroduodenal portion of the gastrointestinal tract: a mathematical model. Computational and Mathematical Methods in Medicine, 2016, vol. 2016, Article ID 5164029, 18 p. DOI: 10.1155/2016/5164029

17. Orlova E.D., Kamaltdinov M.R. Modelirovanie pishchevaritel'nykh protsessov v dvenadtsatiperstnoi kishke [Modeling of digestive processes in the duodenum]. Matematicheskoe modelirovanie $v$ estestvennykh naukakh, 2017, vol. 1, pp. 246-250 (in Russian).

18. Zaitseva N.V., Kiryanov D.A., Lanin D.V., Chigvintsev V.M. A mathematical model of the immune and neuroendocrine systems mutual regulation under the technogenic chemical factors impact. Computational and Mathematical Methods in Medicine, 2014, vol. 2014, Article ID 492489, 12 p. DOI: $10.1155 / 2014 / 492489$

19. Metodologiya otsenki riskov zdorov'yu naseleniya pri vozdeistvii khimicheskikh, fizicheskikh i biologicheskikh faktorov dlya opredeleniya pokazatelei bezopasnosti produktsii (tovarov) / Evraziiskaya ekonomicheskaya komissiya [Methodology of population health risks analysis under exposure to chemical, physical and biological factors aimed at determining safety parameters of products (goods) / the Eurasian economic Commission]. Moscow, Yumanite Media, 2014, 115 p. (in Russian).

20. Residue evaluation of certain veterinary drugs. Meeting 2010-Evaluation of data on ractopamine residues in pig tissues / Joint FAO/WHO Expert Committee on Food Additives. Italy, Rome, 2010, 52 p.

21. Alemanno A., Capodieci G. Testing the Limits of Global Food Governance: The Case of Ractopamine. Eur. J. Risk Regul, 2012, vol. 3, pp. 12.

22. Scientific Opinion of the Panel on Additives and Products or Substances used in Animal Feed (FEEDAP) on a request from the European Commission on the safety evaluation of ractopamine. EFSA J., 2009, vol. 1041, pp. 1-52.

Zaitseva N.V. Analysis of population health risks in the Russian Federation caused by food products contamination. Health Risk Analysis, 2018, no. 4, pp. 13-23. DOI: 10.21668/health.risk/2018.4.02.eng

Received: 13.10 .2018

Accepted: 14.12 .2018

Published: 30.12.2018 